International Journal of Informatics, Economics, Management and Science

http://journal.stmikjayakarta.ac.id/index.php/ijiems

E-ISSN: 2809-8471 (online), P-ISSN: 2809-9281 (Print)

DOI: $10.52362 /$ ijiems.v1i1.667

Volume 1, Issue 1, January 2022, page 1-12

\title{
Impact of Dividend Policy Analysis on Fluctuations in Stock Price of Food and Beverage Companies
}

\author{
Ade Onny Siagian1, * Ninuk Riesmiyantiningtias ${ }^{2}$, Rizky Amalia $^{3}$ \\ ${ }^{1,2,3}$ Department science of accounting, Faculty of Economic, Bina Sarana Informatika University, \\ Jakarta, Indonesia
}

Authors Scopus ID URL:

Ade Onny Siagian ${ }^{1}$, https://www.scopus.com/authid/detail.uri?authorId=57219985838

\section{Email address:}

Email ade.aoy@bsi.ac.id, ninuk.nys@bsi.ac.id, Rizky.ram@bsi.ac.id.

*Corresponding author : ade.aoy@bsi.ac.id

Received: November 30, 2022; Accepted: December 22,2022 ; Published: January 8,2022

\begin{abstract}
This study aims to determine the effect of dividend policy on stock prices in food and beverage companies listed on the Indonesia Stock Exchange. The results of the research of PT Sekar Laut, from the results of the calculation of the correlation analysis obtained the value of the coefficient $=0.33$ which means that it has a very weak relationship or there is no relationship between dividend policy and stock price movements and the coefficient of determination is $10.89 \%$, which means the effect of dividend policy on stock price fluctuation was only $10.89 \%$, the remaining $89.11 \%$ was caused by other factors and for PT. Ultra Jaya, from the results of the calculation of the correlation analysis obtained the coefficient of determination 0.96, meaning that dividends per share have a strong relationship with stock price movements, and the coefficient of determination is $92.16 \%$, which means that the effect of dividend policy on stock price fluctuations is $92.16 \%$, the rest is $92.16 \% .7 .84 \%$ caused by other factors, as well as for PT. Ades Alfindo Putra Setia, from the results of the calculation of the correlation analysis obtained a coefficient of 0.86 (the value of $r$ is close to a positive and strong number) with a determination coefficient of $73.96 \%$, then the effect of dividend policy on stock price fluctuations is $73.96 \%$, the remaining $26.04 \%$ caused by other factors. The value of 96 (the value of $r$ is close to one) means that dividend per share has a strong relationship with stock price movements, and the coefficient of determination is $92.16 \%$, which means that the effect of dividend policy on stock price fluctuations is $92.16 \%$ and the remaining $7.84 \%$ is caused by factors.
\end{abstract}

Keywords: Stock price fluctuation, Dividend policy, Capital market, Firm value

\section{Introduction}

In order to utilize resources and finance all company activities in producing output, large amounts of funds are needed. Companies can obtain these funds from within the company as well as from outside the company. Sources of funds from within the company are in the form of 
International Journal of Informatics, Economics, Management and Science

http://journal.stmikjayakarta.ac.id/index.php/ijiems

E-ISSN: 2809-8471 (online), P-ISSN: 2809-9281 (Print)

DOI: $10.52362 /$ ijiems.v1i1.667

Volume 1 , Issue 1 , January 2022, page 1-12

funds that come from profits invested in the company (retained earnings), profit for the year, private investment or joint participation. However, if the sources from within the company are insufficient, the company can meet its funding needs from outside the company in the form of a capital loan from a bank or by going through the Go Public process in the capital market, namely by selling part of the company's shares to be owned by the public or investors who want to invest their money. in the capital market. defining shares as proof of taking part or a participant in a limited liability company (PT) Bambang Riyanto (2014). For the company concerned, what is received from the sale of shares will remain embedded in the company for life even though the shareholder itself is not a permanent investment because it can be sold at any time.

The capital market is a financial institution that refers to the theory of supply and demand. From the demand side, it can be seen from the large quantity of Indonesia's population which means that it has great potential to become an investor to invest in the market, especially in the form of shares. Meanwhile, from the supply side, the capital market is one an alternative as a place of funding for the business world. This can be seen from the increasing number of companies offering their shares to the public.With the increasing number of companies listed on the capital market, the greater the opportunity for potential investors to make the right and profitable choices in investing their money in companies that sell securities on the capital market. In determining the type of letter to be bought or sold, especially in the form of shares, potential investors should first consider the available information. Because considering that the financing originating from investment in the capital market, the processes and transactions that occur require in-depth knowledge and calculations regarding changes in share prices and the factors that affect those changes. This is very important for companies and potential investors to reduce and minimize the risks that may arise from these investments. The factors that affect stock prices are external factors and internal factors. External factors are factors that come from outside the company that influenceshare price and cannot be controlled by the company, for example investors, government policies, and unpredictable incidental events. Meanwhile, internal factors are factors that come from within the company and can be controlled by the company's management, for example the condition of financial performance, company profits and dividends and other internal factors.

These factors greatly influence the fluctuation of share prices so that shareholders will gain or may gain losses. The benefits received by shareholders can be in the form of dividends or capital gains. Dividends are profits distributed to shareholders in an amount proportional to the number of shares they own, while capital gains are the excess between the selling value and the purchase value of the shares.

The objective of a business entity is to maximize shareholder wealth which can be reflected and the high share price of the business entity. One of the factors that affect share prices is dividend policy, where one of the objectives of the dividend policy is to maximize share prices.According to Weston J. Fred Scrott BESley, Eugene F. Grigham (1996: 50) that the value of the company is reflected in the dividend policy. The optimal dividend policy is one of the factors that can increase the value of the company. This opinion is based on that in the real

DOI: $10.52362 /$ ijiems.v1i1.667

IJIEMS This work is licensed under a Creative Commons Attribution 4.0 International License. 
International Journal of Informatics, Economics, Management and Science

http://journal.stmikjayakarta.ac.id/index.php/ijiems

E-ISSN: 2809-8471 (online), P-ISSN: 2809-9281 (Print)

DOI: $10.52362 /$ ijiems.v1i1.667

Volume 1 , Issue 1 , January 2022, page 1-12

world, investors may prefer dividend policies over others. Thus the dividend policy of business entities is relevant because dividend policy can affect the value of the company through the preferences of investors.Based on the background description above, the objectives of this study can be formulated, namely to determine the effect of dividend policy on stock prices in food and beverage companies listed on the Indonesia Stock Exchange (IDX).

The hypothesis that will be proposed in this study is as follows: "It is suspected that dividend policy has a significant effect on stock prices in food and beverage companies listed on the Indonesia Stock Exchange (IDX)."

\section{Materials and Method}

\subsection{Operational Definition of Variables}

The operational definition of a variable is an object that has a value that is used in a study. The variables tested in this study consisted of 2 kinds of variables:

1. The stock price as the dependent variable $(\mathrm{Y})$ is determined based on the last official exchange rate (closing price) every month from food and beverage companies that have listed their shares in PT. Indonesia Stock Exchange and stated in rupiah units.

2. Dividend Policy as an independent variable (X)

The policy of a company in making decisions whether profits will be distributed as dividends to shareholders or retained as retained earnings. Dividend policy as an independent variable in this study is expressed as dividends per share or dividends per share.

\subsection{Analysis Technique}

In analyzing the data, the analysis techniques used in this study are

\subsection{Simple Linear Regression}

To determine the effect of dividends per share on stock prices, a simple linear regression analysis model is used with the formula:

$$
\text { 1. } \begin{aligned}
& \mathbf{Y}=\mathbf{a}+\mathbf{b x} \\
& \mathbf{b}=\mathbf{n} \cdot \sum \mathbf{X Y}-\sum \mathbf{X} \sum \mathbf{Y} \\
& \mathbf{n} \cdot \sum \mathbf{X}^{\mathbf{2}}-\left(\sum \mathbf{X}\right)^{\mathbf{2}} \\
& \mathbf{a}=\sum \mathbf{Y}-\mathbf{b} \sum \mathbf{X n}
\end{aligned}
$$

Where:

$\mathrm{Y}=$ average share price

$\mathrm{a}=$ Constant

$\mathrm{b}=$ The regression coefficient you are looking for

$\mathrm{X}=$ Dividend perShare

$\mathrm{n}=$ Valueobservation

\subsection{Correlation Coefficient (r)}

This correlation coefficient is used to determine how close the relationship between the share price variable $(\mathrm{Y})$ and the dividend policy variable $(\mathrm{X})$ can be seen with a simple correlation model with the formula:

$$
\mathbf{r}=
$$

n. $\sum \mathbf{X Y}-\sum \mathbf{Y} \cdot \sum \mathbf{X}$

DOI: $10.52362 /$ ijiems.v1i1.667

IJIEMS This work is licensed under a Creative Commons Attribution 4.0 International License. 
International Journal of Informatics, Economics, Management and Science

http://journal.stmikjayakarta.ac.id/index.php/ijiems

E-ISSN: 2809-8471 (online), P-ISSN: 2809-9281 (Print)

DOI: $10.52362 /$ ijiems.v1i1.667

Volume 1, Issue 1, January 2022, page 1-12

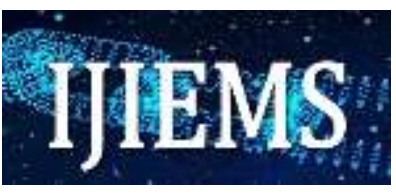

$$
\left.\sum \mathbf{n} \cdot \sum \mathbf{X}^{2}\right]-\sum\left[\mathbf{n} \cdot \sum \mathbf{Y}^{2}\right]-\left[\sum \mathbf{Y}^{2}\right]
$$

Where :

$\mathrm{X}=$ Independent variable of dividend policy (Dividend Per Share)

$\mathrm{Y}=$ The dependent variable of the stock price

$\mathrm{n}=$ Observation value

The simple correlation description used is:

- $\mathrm{r}$ approaches 1 , the relationship between variable $\mathrm{X}$ and variable $\mathrm{Y}$ is perfect and positive (very strong and negative relationship).

- $\mathrm{r}$ approaches -1 , the relationship between variable $\mathrm{X}$ and variable $\mathrm{Y}$ is perfect and negative (the relationship is very strong and negative).

- $\mathrm{r}$ approaches 0 , the relationship between variable $\mathrm{X}$ and variable $\mathrm{Y}$ is very weak or there is no relationship at all.

To prove the hypothesis test, a statistical test is used, namely the $t$ test with the formula:

$$
\mathbf{t}=\frac{\mathbf{b}-\sum}{\mathbf{S b}}
$$

With $\mathrm{df}=\mathrm{n}-\mathrm{k}$ and using a significant level of $5 \%$

\section{Results and Discussion}

Every investor, in investing in the capital market, of course, has the goal of obtaining a return on investments made in the future. Therefore, an investor must know what information is related to the prospects of a company, dividend payments by a company can be used by investors as information and guidance in investing. Dividend payment indirectly contains information and communication from the company to shareholders regarding the probability level of companies that are able to provide dividends to shareholders each year in a stable manner, so it can be estimated that the company's share price is always at a stable level, especially in the conditions of the Indonesian state which less stable both in the economic field, and others, increase the risk when investing in the capital market, therefore investors must be very clever to see stocks that have stable prices. Investors prefer a stable stock price because it can be ensured that the company's financial condition is getting stronger. Therefore, the relevant dividend policy can increase shareholder wealth because investors are interested in buying shares. Of course, in addition to increasing wealth in the future, it also aims to receive dividends or capital gains. Therefore, the relevant dividend policy can increase shareholder wealth because investors are interested in buying shares. Of course, in addition to increasing wealth in the future, it also aims to receive dividends or capital gains. Therefore, the relevant dividend policy can increase shareholder wealth because investors are interested in buying shares. Of course, in addition to increasing wealth in the future, it also aims to receive dividends or capital gains.

The purpose of establishing a policy by the company regarding its dividend distribution is to maximize the wealth of its shareholders and a decision on whether the company's profits will be distributed as dividends or not but retained as retained earnings. This is very important because it will have an effect as

DOI: $10.52362 /$ ijiems.v1i1.667

IJIEMS This work is licensed under a Creative Commons Attribution 4.0 International License. 
International Journal of Informatics, Economics, Management and Science http://journal.stmikjayakarta.ac.id/index.php/ijiems

E-ISSN: 2809-8471 (online), P-ISSN: 2809-9281 (Print)

DOI: $10.52362 /$ ijiems.v1i1.667

Volume 1 , Issue 1 , January 2022, page 1-12

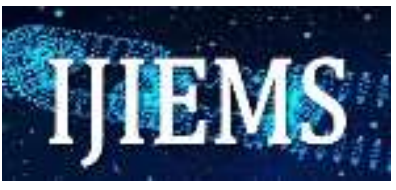

a consideration in investing one of the most important sources of funds to finance company growth. Meanwhile, dividends are cash flows that are paid to shareholders. Every company will always want growth for its company on the one hand and can also pay dividends to shareholders on the other, but these goals are always conflicting. The higher the dividend payment by a company will reduce the company's ability to invest, so that it will inhibit the rate of growth in income and will further reduce its share price. Large dividend payments tend to result in the company's share price. This shows that the level of company profitability is good at that time.

Thus it can be said that the higher the dividend payment determined by a company, the smaller the funds available to be reinvested in the company. One of the most important functions in a financial manager is to determine the allocation of net profit after tax, whether the income is for dividend payments on the one hand or for retained earnings on the other hand. Where this decision has an influence that can determine the value of a company (volue of the firm) and if the company is wrong in determining which policy to use it will result in losses for the company.

\subsection{Hypothesis test}

In this research, there is an independent variable, namely dividend per share to analyze the data and answer the hypothesis in this study, then the value of the independent variable must be displayed. first before testing the hypothesis, namely dividends per share and stock prices.

\subsection{Operational Variable Calculation}

Table 1: Annual Average Share Price (Y) 2016 - 2019

\begin{tabular}{|c|l|r|l|l|r|l|}
\hline No. & Company & $\mathbf{2 0 1 6}$ & $\mathbf{2 0 1 7}$ & $\mathbf{2 0 1 8}$ & $\mathbf{2 0 1 9}$ & $\begin{array}{l}\text { Average / } \\
\text { Year }\end{array}$ \\
\hline \multirow{2}{*}{1} & PT. Sekar Laut & 1,512 & $1,860.5$ & 1,349 & 2004 & $1,681.5$ \\
2 & PT. Ultra Jaya & 3,173 & 2,437 & 2,725 & 3,196 & 2,754 \\
3 & PT. Ades Alfindo & 2,658 & 1,942 & 2,875 & 3,829 & $2,954.75$ \\
& Faithful Son & & & & & \\
\hline & Company & $2,447.83$ & $2,079.83$ & 2,301 & $3,000.67$ & \\
\hline
\end{tabular}

Data source: PT. Indonesia stock exchange

Table 1 shows that the Food and Beverage company which has the highest average share price per year occurs at PT Ades, namely Rp. 2954.75 while the one with the lowest average share price per year is at PT. Sekar Laut is Rp. 1681.5 and if seen from the industry average which has the highest industry average is in 2019, namely Rp. 3009.67, while the lowest industry average in 2017 was Rp. 2079.83 from all research samples.

The data regarding dividends per share or dividends per share at the end of the year food and beverage companies can be seen in table 2 .

Table 2: Dividend Per Share or Dividend Per Share 2016 - 2019

DOI: $10.52362 /$ ijiems.v1i1.667

IJIEMS This work is licensed under a Creative Commons Attribution 4.0 International License. 
International Journal of Informatics, Economics, Management and Science

http://journal.stmikjayakarta.ac.id/index.php/ijiems

E-ISSN: 2809-8471 (online), P-ISSN: 2809-9281 (Print)

DOI: $10.52362 /$ ijiems.v1i1.667

Volume 1, Issue 1, January 2022, page 1-12

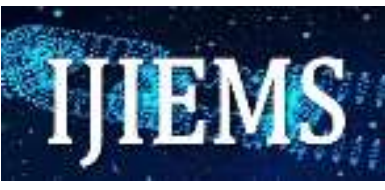

\begin{tabular}{|c|l|r|r|r|r|r|}
\hline No. & \multicolumn{1}{|c|}{ Company } & $\mathbf{2 0 1 6}$ & $\mathbf{2 0 1 7}$ & $\mathbf{2 0 1 8}$ & $\mathbf{2 0 1 9}$ & $\begin{array}{l}\text { Avera } \\
\text { ge / } \\
\text { Year }\end{array}$ \\
\hline \multirow{2}{*}{$\begin{array}{l}\text { PT Sekar Laut } \\
2\end{array}$} & $\begin{array}{l}\text { PT. Ultra Jaya } \\
\text { PT.AdesAlfindo Putra }\end{array}$ & 35.05 & 44.79 & 61.23 & 65 & 54.77 \\
& Loyal & & 46.27 & 55.77 & 59.43 & 35.75 \\
& & 38.87 & 42.91 & 47.67 & 56.98 & 49.17 \\
\hline
\end{tabular}

Data source: PT. Indonesia stock exchange

Table 2 shows that the food and beverage companies that have the highest average dividend per share are PT. Sekar Laut, which is Rp. 54.77 while the lowest average dividend per share was at PT. Ultra Jaya, which is Rp. 35.75, and if viewed from the industry average the highest was in 2019 amounting to Rp.56.8 while the lowest industry average was in 2016 amounting to Rp. 38.87 from all research objects.

\subsection{Analysis of Result of Proof of Hypothesis}

1. Simple linear regression equation analysis

This analysis is used to show how an independent variable $(\mathrm{X})$ dividend per share affects a dependent variable (Y) stock prices at food and beverage companies listed at PT. Indonesia stock exchange.

Formula :

$$
\begin{aligned}
& \mathrm{Y}=\mathrm{a}^{2} \mathrm{bx} \\
& \mathrm{b}=\frac{\mathrm{n} \cdot \mathrm{XY}-\sum \mathrm{X} \sum \mathrm{Y}}{\mathrm{n} \sum \mathrm{X} 2\left(\sum \mathrm{X}\right)^{2}} \\
& \mathrm{a}=\frac{\begin{array}{l}
\sum \mathrm{Y}-\mathrm{b} \sum \mathrm{X} \\
\mathrm{n}
\end{array}}{}
\end{aligned}
$$

\section{Where :}

$\mathrm{Y}=$ Average share price

$\mathrm{a}=$ Constant

$\mathrm{b}=$ To measure the magnitude of the influence of $\mathrm{X}$ on Y quantitatively

$\mathrm{X}=$ Dividend per share

$\mathrm{n} \quad=$ Number of years

\subsubsection{PT. Now The Sea}

Table 3: Regression Calculations

\begin{tabular}{|c|c|c|c|c|c|}
\hline Year & $X$ & $Y$ & $X^{2}$ & $Y^{2}$ & $X Y$ \\
\hline 2016 & 48.05 & 2658 & 2308.80 & 7064964 & 127716.9 \\
\hline
\end{tabular}


International Journal of Informatics, Economics, Management and Science

http://journal.stmikjayakarta.ac.id/index.php/ijiems

E-ISSN: 2809-8471 (online), P-ISSN: 2809-9281 (Print)

DOI: $10.52362 /$ ijiems.v1i1.667

Volume 1 , Issue 1 , January 2022, page 1-12

\begin{tabular}{|c|c|c|c|c|c|}
\hline 2017 & 44.79 & 2437 & 2007.14 & 5938969 & 109153.23 \\
\hline 2018 & 61.23 & 2725 & 3749.11 & 7425625 & 166851.75 \\
\hline 2019 & 65 & 3196 & 4225 & 10214416 & 207740 \\
\hline$\sum$ & 219.07 & 11016 & 12289.05 & 30643974 & 611461.88 \\
\hline
\end{tabular}

Data source: PT. Indonesia stock exchange

$$
\begin{aligned}
\mathrm{b} & =\frac{\mathrm{n} . \mathrm{XY}-\sum \mathrm{X} \sum \mathrm{Y}}{\mathrm{n} \sum \mathrm{X} 2\left(\sum \mathrm{X}\right)^{2}} \\
& =\frac{4.247740 .43-(143)(6726)}{4,5321.33-(143) 2} \\
& =\frac{29143.72}{836.32} \\
& =\frac{34.8}{\mathrm{a}} \\
& =\frac{\mathbf{n} \sum \mathrm{b}}{4} \\
& =\frac{6726-(34.8)(143)}{437.4} \\
& =\frac{Y}{437.4+(34.8)}
\end{aligned}
$$

So the regression equation is $\mathrm{Y}=437.4+(34.8)$ slop linear regression equation $(b)=34.8$ explaining the magnitude of the influence of $\mathrm{x}$ on $\mathrm{y}$ means that any increase in dividends per share of $1 \%$ in a positive direction will be followed by an increase in prices shares in the same direction as large as the regression coefficient of Rp. 34.8.

\subsubsection{PT. Ultra Jaya}

Table 4: Regression Calculations

\begin{tabular}{|c|c|c|c|c|c|}
\hline Year & $\mathrm{X}$ & $\mathrm{Y}$ & $\mathrm{X}^{2}$ & $\mathrm{Y}^{2}$ & $\mathrm{XY}$ \\
\hline 2016 & 35.19 & 3173 & 1238.34 & 10067929 & 111657.87 \\
\hline 2017 & 46.27 & 1942 & 2140.91 & 3771364 & 89856.34 \\
\hline 2018 & 55.77 & 2875 & 3110.29 & 8265625 & 160338.75 \\
\hline 2019 & 59.43 & 3829 & 3531.92 & 14661241 & 227557.47 \\
\hline$\sum$ & 196.66 & 11819 & 10021.46 & 36766159 & 589410.43 \\
\hline
\end{tabular}

Data source: PT. Indonesia stock exchange

$$
\mathrm{b}=\frac{\mathrm{n} \cdot \mathrm{XY}-\sum \mathrm{X} \sum \mathrm{Y}}{\mathrm{n} \sum \mathrm{X} 2\left(\sum \mathrm{X}\right)^{2}}
$$


International Journal of Informatics, Economics, Management and Science

http://journal.stmikjayakarta.ac.id/index.php/ijiems

E-ISSN: 2809-8471 (online), P-ISSN: 2809-9281 (Print)

DOI: 10.52362 /ijiems.v1i1.667

Volume 1, Issue 1, January 2022, page 1-12

$$
\begin{aligned}
& =\frac{4.589410 .43-(196.66)(11819)}{4,10021.46-(196.66)^{2}} \\
& =\frac{33317.18}{1410.68} \\
& =\frac{23.62}{\mathrm{a}}=\frac{\sum \mathrm{Y}-\mathrm{b} \sum \mathrm{X}}{4} \\
& =\frac{11819-(23.62)(196.66)}{4} \\
& =1703.47
\end{aligned}
$$

So the regression equation is $\mathrm{Y}=1793.47+(23.62)$ slop linear regression equation $(b)=23.62$ explaining the magnitude of the influence of $\mathrm{x}$ on y means that every $1 \%$ increase in dividends per share in a positive direction will be followed by an increase in prices. shares in the same direction as large as the regression coefficient of Rp. 23.62.

\subsubsection{PT. Ades Alfindo Putra Setia}

Table 5: Regression Calculations

\begin{tabular}{|c|c|c|c|c|c|}
\hline Year & $\mathrm{X}$ & $\mathrm{Y}$ & $\mathrm{X}^{2}$ & $\mathrm{Y}^{2}$ & $\mathrm{XY}$ \\
\hline 2016 & 48.05 & 2658 & 2308.8 & 7064964 & 127716.9 \\
\hline 2017 & 44.79 & 2437 & 2007.14 & 5938969 & 109153.23 \\
\hline 2018 & 61.23 & 2725 & 3749.11 & 7425625 & 166851.75 \\
\hline 2019 & 65 & 3196 & 4225 & 10214416 & 207740 \\
\hline$\sum$ & 219.07 & 11016 & 12289.05 & 30643974 & 611461.88 \\
\hline
\end{tabular}

Data source: PT. Indonesia stock exchange

$$
\begin{aligned}
\mathrm{b} & =\frac{\mathrm{n} . \mathrm{XY}-\sum \mathrm{X} \sum \mathrm{Y}}{\mathrm{n} \sum \mathrm{X} 2\left(\sum \mathrm{X}\right)^{2}} \\
& =\frac{4.611461 .88^{2}(219.07)(11016)}{4.12289 .05^{2}(219.07) 2} \\
& =\quad 32572.5 \\
& =27.96
\end{aligned}
$$


International Journal of Informatics, Economics, Management and Science

http://journal.stmikjayakarta.ac.id/index.php/ijiems

E-ISSN: 2809-8471 (online), P-ISSN: 2809-9281 (Print)

DOI: $10.52362 /$ ijiems.v1i1.667

Volume 1 , Issue 1 , January 2022, page 1-12

$$
\begin{aligned}
a & =\frac{\sum Y-b \sum X}{n} \\
& =\frac{11016-(27.96)(219.02)}{4} \\
& =\frac{11016-6123.8}{4} \\
& =1223.05
\end{aligned}
$$

So the regression equation is $\mathrm{Y}=1223.05+(27.96) \mathrm{x}$ slop linear regression equation $(\mathrm{b})=27.96$ explaining the magnitude of the influence of $\mathrm{x}$ on $\mathrm{y}$. This means that every $1 \%$ increase in dividends per share, in a positive direction, will be followed by an increase in share prices in the same direction as the regression coefficient of Rp. 27.96.

\section{Table 6: Recapitulation of Correlation Value Calculation Results}

\begin{tabular}{|c|l|c|c|c|c|c|}
\hline No. & Company & $\mathbf{R}$ & $\begin{array}{c}\text { T } \\
\text { testcount }\end{array}$ & $\begin{array}{c}\text { ttabl } \\
\mathbf{e}\end{array}$ & $\begin{array}{c}\text { Accepted / } \\
\text { Rejected }\end{array}$ & Significant / not \\
\hline 1 & $\begin{array}{l}\text { PT. Ultra } \\
\text { Jaya }\end{array}$ & $\begin{array}{c}0.9 \\
6\end{array}$ & 4,8 & 4,303 & $\begin{array}{c}\text { Ho was } \\
\text { rejected }\end{array}$ & $\begin{array}{c}\text { Has a strong and } \\
\text { significant } \\
\text { correlation to Y }\end{array}$ \\
\hline 2 & $\begin{array}{l}\text { PT. Sekar } \\
\text { Laut }\end{array}$ & 0.3 & 0.49 & 4,303 & $\begin{array}{c}\text { Ho } \\
\text { accepted }\end{array}$ & $\begin{array}{c}\text { The variable } \mathrm{x} \text { has a } \\
\text { correlation which is } \\
\text { not significant } \\
\text { to variable Y }\end{array}$ \\
\hline 3 & $\begin{array}{l}\text { PT. Ades } \\
\text { Alfindo Putra } \\
\text { Setia }\end{array}$ & 0.8 & 2.38 & 4,303 & $\begin{array}{c}\text { Ho } \\
\text { accepted } \\
\text { The variable x has } \\
\text { an insignificant } \\
\text { correlation to the } \\
\text { variable Y }\end{array}$ \\
\hline
\end{tabular}

\subsection{Determine the amount of the coefficient of determination ( $r 2)$.}

To determine the magnitude of the influence of dividend policy on fluctuations in stock prices of food and beverage companies listed on the Indonesia Stock Exchange. Can be determined by calculating the analysis of the coefficient of determination (r2)

a. PT. Ultra Jaya

Based on the results of calculations with correlation analysis, it is known that the correlation coefficient is $\mathrm{r}=0.96$, based on the calculation of the correlation coefficient, the coefficient of determination can then be calculated, namely $\mathrm{r} 2=(0.96) 2=0.9216=92.16 \%$ which means the effect of dividend policy on stock price fluctuations at PT. Ultra Jaya at $92.16 \%$, the remaining $7.84 \%$ due to other factors, for example: economic conditions, political stability, banking policies, bank interest rates, foreign exchange rates and so on which are not discussed in this study.

b. PT. Sekar Laut.

DOI: $10.52362 /$ ijiems.v1i1.667

IJIEMS This work is licensed under a Creative Commons Attribution 4.0 International License. 
International Journal of Informatics, Economics, Management and Science

http://journal.stmikjayakarta.ac.id/index.php/ijiems

E-ISSN: 2809-8471 (online), P-ISSN: 2809-9281 (Print)

DOI: $10.52362 /$ ijiems.v1i1.667

Volume 1 , Issue 1 , January 2022, page 1-12

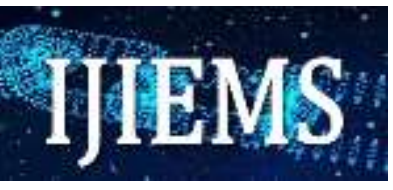

Based on the results of calculations with correlation analysis, it is known that the correlation coefficient is $r=0.33$, based on the calculation of the correlation coefficient, the coefficient of determination can then be calculated, namely $\mathrm{r} 2=(0.33) 2=0.1089=10.89 \%$, which means that the effect of dividend policy on stock price fluctuations at PT. Sekar Laut was $10.89 \%$, the remaining $89.11 \%$ was caused by other factors, for example: economic conditions, political stability, banking policies, bank interest rates, foreign exchange rates and so on which were not discussed in this study.

c. PT. Ades Alfindo Putra Setia

Based on the results of calculations with correlation analysis, it is known that the correlation coefficient is $\mathrm{r}=0.86$, based on the calculation of the correlation coefficient, the coefficient of determination can then be calculated, namely $\mathrm{r} 2=(0.86) 2=0.7396=73.96 \%$ which means the effect of dividend policy on stock price fluctuations at PT. Ades Alfindo Putra Setia with $73.96 \%$, the remaining $26.04 \%$ due to other factors, for example: economic conditions, political stability, banking policies, bank interest rates, foreign exchange rates and so on which are not discussed in this study.

\section{Conclusion}

Based on the results of the discussion analysis that the author conducted on three Food and Beverage companies as research samples for four years from 2016 to 2019 on the Indonesia Stock Exchange, conclusions can be drawn:

1. Based on the results of calculations using simple linear regression, PT. Sekar Laut is $Y=$ $437.4+34.8 \mathrm{X}$. This means that the regression coefficient is 34.8 on the independent variable (X). This means that every $1 \%$ increase in dividends per share will be followed by an increase in the company's share price. From the calculation of the coefficient analysis, it is found that the correlation coefficient at PT. Sekar Laut $r=0.33$, then the value of $r$ approaches the number 0 means dividend per share $(\mathrm{X})$ has a very weak or no relationship to stock price movements $(\mathrm{Y})$, while the amount of variable $\mathrm{X}$ to variable $\mathrm{Y}$ is indicated by the coefficient the regression produces a tcount of 4.86>2.353, so it can be said that the coefficient has no significant effect on stock prices.

Based on the coefficient of determination (r2) of 0.1089 or $10.89 \%$, the effect of dividend policy on stock price fluctuations is $10.89 \%$ and the remaining $89.11 \%$ is caused by other factors, for example: economic conditions, political stability, banking policy, deposit interest rates, foreign exchange rates.

2. PT. Ultra Jaya's equation is $\mathrm{Y}=1793+23.62 \mathrm{X}$. This means that the regression coefficient is 23.62 on the independent variable (X). This means that each dividend increase is as large $1 \%$, it will be followed by an increase in the company's share price. From the calculation of the correlation coefficient analysis, it is found that the correlation coefficient value at PT. Ultra Jaya $r=0.96$, the value of $r$ is close to one which means that dividend per share $(\mathrm{X})$ has a relationship to stock price movements. While the magnitude of the influence of variable $\mathrm{X}$ on variable $\mathrm{Y}$ is shown by the regression coefficient of the equation above, the regression coefficient is tested to produce a t count of $0.49<2.353$ so that it can be said that the coefficient

DOI: $10.52362 /$ ijiems.v1i1.667

IJIEMS This work is licensed under a Creative Commons Attribution 4.0 International License. 
International Journal of Informatics, Economics, Management and Science

http://journal.stmikjayakarta.ac.id/index.php/ijiems

E-ISSN: 2809-8471 (online), P-ISSN: 2809-9281 (Print)

DOI: $10.52362 /$ ijiems.v1i1.667

Volume 1 , Issue 1 , January 2022, page 1-12

has a strong correlation between variables per share, there are stock price variables which means the coefficient not significant.

Based on the coefficient of determination (r2) of 0.9216 or $92.16 \%$, the effect of dividend policy on stock price fluctuations is $92.16 \%$ and the remaining $7.84 \%$ is due to other factors, for example: economic conditions, political stability, banking policy, deposit interest rates, foreign exchange rates.

3. PT. Ades Alfindo Putra Setia, the equation is $Y=1223.05+27.96 \mathrm{X}$, this means that the regression coefficient is 27.96 on the independent variable $(\mathrm{X})$. This means that every $1 \%$ increase in dividends will be followed by an increase in the company's share price. From the calculation of the correlation coefficient analysis, it is found that the correlation coefficient value at PT. Ades Alfindo Putra Setia $r=0.86$, the value of $r$ is close to a positive number one means dividend $(\mathrm{X})$ has a relationship to stock price movements $(\mathrm{Y})$, while the amount of variable $\mathrm{X}$ to variable $\mathrm{Y}$ is shown by the regression coefficient of the equation above, the regression coefficient is tested to produce a tcount of magnitude $2.74<2.353$, so it can be said that the coefficient has a strong correlation between variables per share to the variables of stock prices, which means that the coefficient is not significant.

Based on the coefficient of determination (r2) of 0.7396 or $73.96 \%$, the effect of dividend policy on stock price fluctuations is $73.96 \%$ and the remaining $26.04 \%$ is due to other factors, for example: economic conditions, political stability, banking policy, deposit interest rates, foreign exchange rates.

\section{Acknowledgements}

The author would like to thank one of the employees at the Jakarta Stock Exchange (JSE) who has provided material and moral support in writing this article. We also thank the IJIEMS Journal for providing the opportunity to share knowledge

\section{References}

[1] Agus Sartono, Financial Management (Theory and Application), third edition, BPFE Publisher, Yogyakarta, 2016.

[2] Bambang Riyanto, Basics of Corporate Spending, 3rd Edition, Gajah Mada Publishing Agency Foundation, Yogyakarta, 2014

[3] James C Varr. Horne, John M Wachauwys JR, Principles of Financial Management, Indonesian Edition, Salemba Empat Publisher.2018

[4] Kamaruddin Ahmad, Fundamentals of Investment Management, First Edition, Publisher Rineka Cipta, Jakarta, 1996

[5] N Riesmiyantiningtias, AO Siagian, Analyisis of Financial Statementss for Assessing Company's Financial Perfomance At PT. Midi Indonesia TBK, Journal of Akrab Juara, 5 (4), 2020, pp. 244-254.

DOI: $10.52362 /$ ijiems.v1i1.667

IJIEMS This work is licensed under a Creative Commons Attribution 4.0 International License. 
International Journal of Informatics, Economics, Management and Science

http://journal.stmikjayakarta.ac.id/index.php/ijiems

E-ISSN: 2809-8471 (online), P-ISSN: 2809-9281 (Print)

DOI: $10.52362 /$ ijiems.v1i1.667

Volume 1 , Issue 1 , January 2022, page 1-12

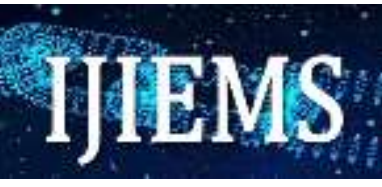

[6] Napa J Awat, Mathematical Approach Financial Management, First Edition, PT. Gramedia Pustaka Utama, Jakarta, 2019.

[7] Sawidji Widoatmojo, Healthy Way of Investing in the Capital Market, PT. Jurnalindo Aksara Grafika, Jakarta, 2016.

[8] Siagian, AO, N Indra, Accounting Knowledge of Micro, Small and Medium Enterprises (MSMEs) for Financial Statements, Journal of Syntax Literate, 4 (12), 2019, pp.17-35. DOI: http://dx.doi.org/10.36418/syntax-literate.v4i12.825

[9] Siagian, AO, The Influence of Third Party Funds, Bank Capital, Number of Branch Offices, Interest Rates and Amount of Money Supply to SOE Bank MSME Loans, Journal of Syntax Literate, 5 (5), 2020, pp. 1-17. DOI: http://dx.doi.org/10.36418/syntaxliterate.v5i5.1140

[10] Siagian, AO, Contribution of Inventory Accounting Systems in Improving Inventory Internal Control, Journal of Social Science, 1 (2), 2020 pp. 1-6. http://jsss.co.id/index.php/jsss/article/view/12

[11] Siagian, AO, The Relationship of Marketing Managerial Individuality in Facing the Industrial Revolution 4.0, Especially in Manufacturing Companies in Central Java, Journal of Syntax Literate, 5 (10), 2020, pp. 980-994. DOI: http://dx.doi.org/10.36418/syntax-literate.v5i10.1669

[12] Siagian AO, TF Prasetyo, 2020. Competency Development Strategy for Small and Medium Enterprises in Jombang Regency. Journal of Akrab Juara 5 (4), 2020, pp. 77-85. http://www.akrabjuara.com/index.php/akrabjuara/article/view/1263.

[13] Siagian, AO, Gunartin, K Nufus, HS Nur'aini Yusuf, A Maddinsyah, A Muchtar. Journal of A Systematic Literature Review of Education Financing Model in Indonesian School. 2020.

[14] Siagian, AO, Analysis of the Effect of Cost of Corporate Social Responsibility, Capital Structure and Liquidity on Profitability in Mining Companies Listed on the Indonesia Stock Exchange, University of North Sumatra. 2019.

[15] Siagian, AO, N Riesmiyantiningtias, General Ledger Making and Balance Sheet Training for Service companies at PPQ Nahwa Nur Bogor, Journal of Aksara Public 4 (4), 2020, pp. 179-188

[16] Siagian, AO, Analysis Of The Effect Of Occupational Safety And Health On Employee Performance Of PT. Wijaya Karya (Persero) TBK. At The Nayumi Sam Tower Malang Project, International Journal of Business and Information Technology 1 (1), 2020. 